\title{
Behavior Trend of Buying Mask as A New Lifestyle for Women in The City of Surabaya During Pandemic
}

\author{
Febriandita Tedjomurti $^{1 *}$, Bagong Suyanto ${ }^{2}$ \\ ${ }^{1,2}$ Faculty of Social Science and Political Science, Airlangga University, Surabaya, \\ Indonesia \\ Email: febriandita.tedjomurti-2018@ fisip.unair.ac.id/ fe.andita@gmail.com \\ Email: bagong_fisip@yahoo.com
}

\begin{abstract}
The spread of the COVID-19 in Indonesia has changed various aspects of the life of the Indonesian people. The lifestyle of the people in the city of Surabaya which is advanced and modern makes the community, especially women, pay attention to their appearances. This causes the trend of masks circulating in society today to become increasingly diverse following the wishes of consumers. This research wants to see how the phenomenon of buying masks by women in Surabaya has become part of the lifestyle during the pandemic. The method used was data collection techniques carried out in two stages, primary namely questionnaires and in-depth interviews as a complement to secondary information, namely with data from various sources such as journals, books, web, and other data center agencies. The respondents interviewed were selected purposively with predetermined criteria. After all, data is processed, the data findings are interpreted and analyzed using the consumerism theory of Jean Baudrillard. This research resulted in the conclusion that most women in the city of Surabaya bought this type of cloth mask. Women in the city of Surabaya consider that masks not only have a health function as the main factor but also must have a fashion function.
\end{abstract}

Keywords: mask, life style, woman, pandemic Covid-19

Paper type: Research paper

*Corresponding author: febriandita.tedjomurti-2018@ fisip.unair.ac.id

Submited: 2021-03-08; Accepted: 2021-04-28; Published: 2021-04-29

Cite this document: Tedjomurti, Febriandita, and Bagong Suyanto. (2021). Behavior Trend Of Buying Mask As A New Lifestyle For Women In The City Of Surabaya During Pandemic. The Journal of Society and Media, 4(2), 199-217. DOI: 10.26740/jsm.v4n2.p199-217. 


\section{INTRODUCTION}

The first case of Covid-19 occurred in Indonesia in March 2020. In the beginning of the month, COVID-19 was first declared positive. Slowly but sure, the virus is spreading to every region in Indonesia. The number of people affected every day is increasing, accompanied by the deaths because they were too late to take precautions. To ensure public safety, the Government issued several policies related to reducing the increasing number of patients. They are doing Large-Scale Social Restrictions (PSBB) carried out gradually in various regions in Indonesia, doing social distancing (keeping distance) when in public spaces, washing hands with soap until clean, and wearing a face mask to protect from COVID-19.

Wearing a mask is 'a must' for everybody who is going out for work, errands, or physical activity. The government recommended masks as one of the important items that must be used by the public to prevent the spread of the Masks have several functions, namely avoiding exposure to air pollution, preventing the transmission and spread of diseases, such as talking, singing, coughing or sneezing, protecting the face from the negative effects of sunlight and pollution, also preventing from touching the face so that one's hands as the most vulnerable parts of the body to exposure to the virus do not move to the face. Masks are used as part of a comprehensive strategy to combat the spread of COVID-19. Previously, only people at high risk of being infected with the COVID-19 virus were required to wear masks. However, after further research, the World Health Organization (WHO) and the government recommended the use of masks for everyone who does outdoor activities. Several types of masks can be used by the community, these types of masks are N95 masks, medical 2 or 3 layer masks, and cloth masks (WHO 2020). For healthy people who do not fall into that category, it is recommended to wear a cloth mask. During the COVID-19 pandemic, the supply of commercially produced respirators and face masks have not been able to meet the suddenly increasing public demand. To solve this problem, cloth masks must be washed frequently. The Centers for Disease Control and Prevention in the U.S. have guided the general public to use alternatives, such as cloth masks to slow the spread of COVID-19. The CDC recommends using tightly textured cotton fabrics, such as cotton, or t-shirts as an option when outdoors. One of the studies measured the breathing ability, and the ability to block nanoparticles, the study found that all these fabrics have a lot of efficient 
Tedjomurti: Behavior Trend Of Buying

Mask As A New Lifestyle For Women In

The City Of Surabaya During Pandemic

materials in blocking high-speed droplets. With 2 or 3 layers, even highly permeable fabrics achieve droplet blocking efficiency similar to medical masks while maintaining breathable comparisons (Aydin et al. 2020).

This long-lasting pandemic affects various areas of life. The examples are social, economic, educational, and tourism. For months people have been living with new habits to avoid virus attacks and the term is known as "The New Normal". In this context, the term can be used to indicate that something previously abnormal was considered a habit. All sectors of life in Indonesia, almost slow down during this pandemic, so that people make changes and adapt quickly. People do various activities that they usually do virtually, such as learning, working, shopping, physical exercising from home. In addition, always washing hands and wearing masks in public spaces are the new normal activities carried out by the community. Various habits that are always carried out by this society merge into a new lifestyle inevitably. Wearing cloth masks is proven to prevent disease transmission effectively and thus has become the new normal in the community during the COVID-19 pandemic. The surge in demand for medical masks and respirators has led to a global shortage of supplies and raw materials. As a result, many people are forced to make their masks, recycle used masks, or choose masks that offer less protection than is needed. Therefore, researchers and industry players have worked hard to overcome the problem of the shortage of masks (Chua et al. 2020). Due to the availability of masks for health workers experiencing a crisis, including N95 masks, in some countries non-medical masks, such as cloth masks recommended for use by communities (Matusiak et al. 2020). This situation provides an opportunity for economic actors, especially in Indonesia, to attract consumers. By utilizing the obligation to wear masks, they develop the ideas and creativity in making masks. So, currently, there are many variations of masks with a variety of motifs, colors, and decorations in various shopping platforms that attract consumers, particularly, female consumers. They tend to be more easily tempted to buy items that look attractive. The previous study found that women have more potential to behave consumptively compared to men (Sumartono 2002). Moreover, it is supported by urban life, especially in Surabaya as one of the advanced metropolitan cities in Indonesia, where facilities and infrastructure to support a modern lifestyle are available. 
Masks have a variety of types, and of course, have different functions according to their respective uses for each person who wears them. However, nowadays the function of masks for society, especially women, is not just about health but also for mode. After seeing the development of creativity of economic actors in developing various models of masks and changes in people's lifestyles during the pandemic, researchers wanted to see how consumer behavior, especially women in the purchase of masks in Surabaya and further linked to the theory of consumerism from Jean Baudrillard. The theory of consumerism is the logic of exchange rate and use-value in consumption has rendered all activities equal, differences in the use-value of goods and services are not possible because they all signify the same thing. This study aims to find out the behavior of the trend of purchasing masks in women in Surabaya who have become part of a new lifestyle during the COVID-19 pandemic in Indonesia. In addition, the results of this study can be used as a reference or benchmark for economic actors in determining the products to be sold to consumers. The novelty of this study lies in taking a different approach, using a cross-disciplinary perspective, and used sociology's theory to analyze the findings in this study, compared to other studies from health and economy disciplinary. The next novelty in this study is about the location, the city of Surabaya was chosen as the research setting because previously no one had researched with a similar theme in Surabaya. The last one, the subject of this study was only women were selected as research subjects so that the findings could be more specific and make the difference compared with other studies that did not specify the research subject.

\section{METHOD}

This research tried to combine the types of survey research and in-depth qualitative research. This research was conducted in Surabaya. Surabaya was chosen to represent the characteristics of urban communities that have a modern life and a fairly heterogeneous society in various aspects of life. 
Tedjomurti: Behavior Trend Of Buying

Mask As A New Lifestyle For Women In

The City Of Surabaya During Pandemic

Figure 1.

Research Flow

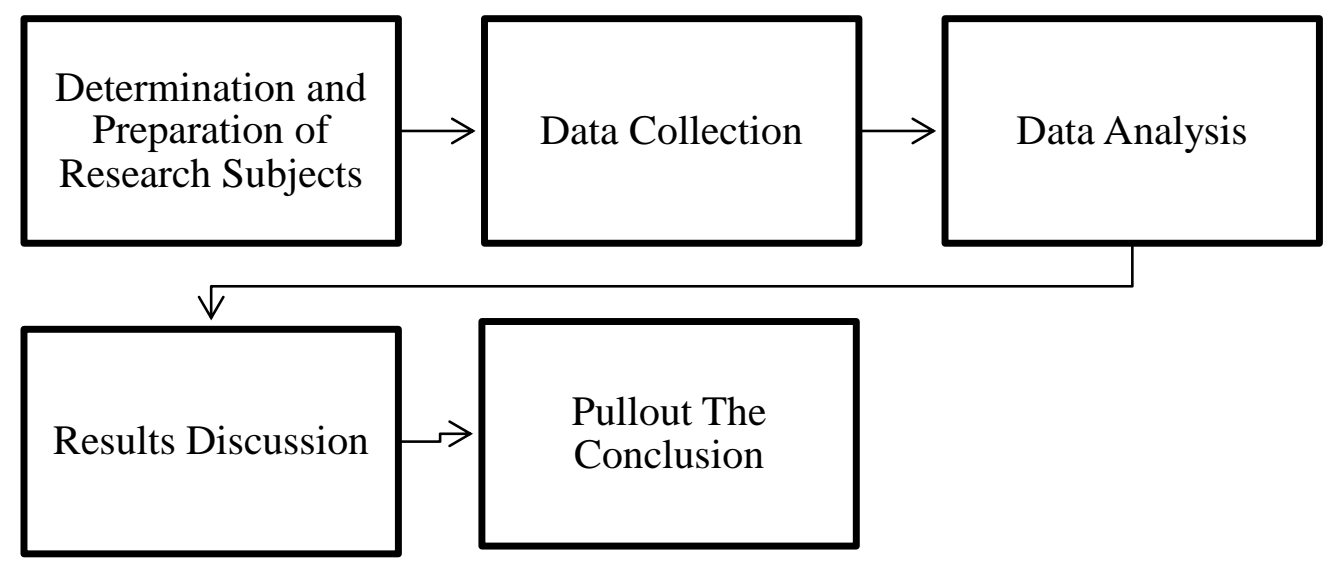

Data collection techniques in this study were carried out in two stages. The first stage was collecting primary data on how women in Surabaya purchased masks during the COVID-19 pandemic. Researchers applied structured questions methods in the form of questionnaires. After going through the validation test, the questionnaire was declared valid. The questionnaires were distributed online because of the situations and conditions during the pandemic that made it impossible to meet face to face. In addition, the study also conducted in-depth interviews with several informants to obtain more in-depth data, especially data that could not be obtained through structured interviews. For in-depth interviews, interviews were conducted by phone and video call. The second phase is collecting population data in Surabaya which possess the data are available at BPS (Central Statistics Agency) is secondary data was obtained as well as various other information from various sources to support this research obtained from journals, and books related to this research.

There were 50 women as the respondents. The 50 respondents who were purposively selected were women who lived in Surabaya, range in age was about 18-30 years old, and had purchased masks during the COVID-19 pandemic. The information unearthed in the interview focused on the situation as well as the background of the purchase of masks during this pandemic. Of the 50 respondents studied, 7 informants with different backgrounds such as college student, career 
woman, housewife, etc were determined to be interviewed in-depth (in-depth interview) to explore more accurate and detailed data to clarify the issues under review. The data that has been collected comes from both primary and secondary data that have been selected for validity. Furthermore, both data were processed. All data from this study were displayed in a concise form so that it is easier for readers to understand and clarify the analysis process. Interpretation is done by discussing the findings of data and theory or comparing from the results of previous studies. After analyzing and interpreting using theory Jean Baudrillard's consumerism. Finally, all the results and discussions were formulated succinctly as the main findings of this study.

\section{RESULT AND DISCUSSION}

The widespread of the COVID-19 virus has a wide impact on every sector of life in Indonesia. Since the Government implemented policies in the form of staying at home, working from home, studying from home as a form of anticipation of the spread of COVID-19, the policy caused many people's changing habits, ranging from education, health, social, technology, to tourism has created new habits in the community known as "The New Normal", no exception for economic activities in Indonesia. One of the things that interest people today is the online shopping platform, following the movement of people who only stay at home. Shopping online is done to meet the daily needs that at the time of this pandemic, tend to increase in demand because to minimize outdoor activities. In addition, based on surveys that have been conducted, it is revealed that buying and selling transactions conducted by Indonesian consumers during this pandemic began to be widely carried out online. This step is considered quite realistic because the public seems to care about health and policies that have been implemented by the government because remembering to go out of the house and go shopping to a shopping center is considered quite risky. After all, it is vulnerable to the spread of the virus.

The use of cloth masks during the COVID-19 virus pandemic is still quite high. The effectiveness of filtration of cloth masks is generally lower than that of medical masks. However, cloth masks provide significant protection when they are well produced and used properly, following guidelines from the Ministry of Health. The multilayer fabric mask ( 2 or 3 layers) is designed to fit the guidelines 
Tedjomurti: Behavior Trend Of Buying

Mask As A New Lifestyle For Women In

The City Of Surabaya During Pandemic

and can cover the chin made of waterproof fabric with a large number of yarn fibers and is smoother, and can provide good protection (Chughtai, Abrar A., Seale, Holly, Macintyre 2020). But in reality, the use of masks by each individual varies. Mask wearers should avoid touching the face and outer surface of their mask. Hand hygiene is also an important factor in the effectiveness of the mask. Therefore, the use of masks should be supplemented with other behavioral changes for the prevention of the spread of the virus. Studies that have been done show the important results about people's behavior in the wearing of masks that are not entirely correct. The use of masks has a very important role in the prevention of diseases especially in the spread of infections in the air, so it must comply with the appropriate provisions. Masks as filters should be worn and carefully adjusted so as not to lose their effectiveness, even if the filtering power is very high as in N95 masks etc. All types of masks must be perfectly attached to cover the nose and mouth along the internal circumference to prevent air from passing from the side (Cumbo and Scardina 2021). The universal use of masks can prevent discrimination from individuals who wear masks when they are unwell because everyone wears masks. The universal use of masks can create new social norms, thus motivating other individuals to wear masks at the beginning of symptoms without fear of stigmatization. Accidental infection in a healthy person by an asymptomatic and asymptomatic person can be avoided. Masks are a real indicator of crisis mode, which can trigger changes in individual behavior such as keeping distance and frequent washing hands (Chua et al. 2020).

Table 1.1

Number of Masks Purchased during the COVID-19 Pandemic

\begin{tabular}{lll}
\hline Quantity & $\begin{array}{l}\text { Number } \\
\text { Respondents }\end{array}$ & of Percentage \\
\hline High $(>20 \mathrm{pcs})$ & 16 & $32 \%$ \\
Moderate $(10-20 \mathrm{pcs})$ & 34 & $68 \%$ \\
Low $(<10 \mathrm{pcs})$ & 0 & $0 \%$ \\
\hline Total & $\mathbf{5 0}$ & $\mathbf{1 0 0 \%}$ \\
\hline
\end{tabular}


This study shows that several data findings, first, the number of masks purchased during the pandemics which is that more than half of respondents, as can be seen in Table 1.1, 68 percent said that they bought 10-20 masks during the COVID-19 pandemic. In addition, 32 percent of respondents said that they bought more than 20 masks during the pandemic, while no one bought less than 10 masks during the pandemic. Some women in Surabaya say that the reason they often buy masks because they need protection when they have activities outside, one of the study's result said that one group showed if $80 \%$ of the population wears a moderately effective mask, nearly half of the projected deaths over the next two months could be prevented (Gandhi, Beyrer, and Goosby 2020). The other reason is tempted by the variety of motifs and models of masks on the market. In addition, the boredom of staying at home that occurred long enough due to the enactment of PSBB in Surabaya caused the time for women to surf and spend time on social media and various shopping platforms to become longer so that it became the main trigger they were tempted to buy masks. One of informant said that she likes to browsing some kinds of stuff that interest her on shopping platforms since she bored and have a lot of time at home during the pandemic, one of stuff that interests her is the mask.

Second, the type of mask purchased that finding in this study was about 66 percent of respondents decided to buy a type of cloth mask because this type of cloth mask has been recommended by the government. Another reason is cloth masks have a more diverse motif and color compared to medical masks. In addition, respondents prefer cloth masks are not only the scarcity of medical masks but also the prices are soaring. This is what makes cloth masks considered the solution to the problem. While 34 percent of respondents prefer to buy the medical mask. The reason they prefer to use medical masks for practical reasons, namely do not need to be washed because it is disposable so that they can be thrown away immediately, to be easier to breathe using medical masks than cloth masks because medical masks are judged to have better respiratory circulation. Masks can be divided into two main groups, medical (surgical) masks and N95 respirators (designed during a pandemic mainly for high-risk medical personnel) (Li et al. 2006). The worsening and prolonged COVID-19 pandemic has led to a surge in daily consumption and demand for PPE goods, including masks, particularly for frontline health workers, resulting in a global shortage of masks 
Tedjomurti: Behavior Trend Of Buying

Mask As A New Lifestyle For Women In

The City Of Surabaya During Pandemic

and raw materials. Unfortunately, the production of masks cannot be improved easily to meet the sudden surge in demand during this pandemic. But as acknowledge that there are limited supplies of medical masks worldwide. Before going into the details of mask use in the community, it is important to first note that they should ensure there is a sufficient supply of face masks for use by healthcare workers first (Paret et al. 2020). As for the general public, reusable cloth masks purchased or made from household materials can serve as a substitute for disposable medical masks. The mask does not provide adequate protection against the virus for health workers who work and constantly make contact with infected patients for hours. These workers require the use of a Filtering Facepiece Respirator (FFR) such as N95 masks as part of their PPE, which offers more protection against airborne pathogens compared to disposable 3-layer medical masks. This mask should be intended for single-use use and is not recommended for re-use. The supply is shortage faced by various countries and hospitals, especially those that do not have sufficient supplies of masks, leading to desperate measures, such as decontamination and re-use of masks (Chua et al. 2020). But use of 1 layer cloth masks such as scuba and buff strongly discouraged, because it does not have sufficient protection against the SARS-CoV 2 virus aerosol particles (Atmojo et al. 2020). The informants said that they buy cloth masks because they are recommended by the government. They admitted that they did not want to take risks later if they had to be reprimanded by the authorities while they were outside the room.

Homemade masks 2 or 3 layers with the most common fabrics can help to prevent the spread of the virus from infected individuals and to protect healthy individuals from inhaling the virus, with similar efficiency to commercial medical masks. Another study also investigated the use of different materials on the effective filtration ability of masks for daily use. They show that different combinations of materials such as cotton and silk could be more effective than just one material. In addition, they revealed that solidly woven cotton provides much better protection than cotton with looser weaves. Proper installation is essential to avoid leakage. The researcher recommends the use of cotton cloth masks that have a high protective effect and few obstructions when breathing (Matuschek et al. 2020). Taking into account the findings in the context of the latest study on the 
filtration efficiency of aerosol fabrics and epidemiological models of the potential impacts of the use of masks, it is found that during pandemics and conditions lacking medical masks, artificial fabric masks with multiple layers can be effective against the transmission of respiratory infections. The use of masks by each individual, supported by counseling and training in making the right masks and proper use, can be an effective strategy in reducing disease transmission (Aydin et al. 2020). Unlike disposable medical masks, cloth masks can be washed and reused so the careful use of cloth masks is to be considered. In general medical masks are made of non-biodegradable plastics such as polypropylene. The review study said that using a cloth mask is much better compared to not wearing a mask at all (Putri 2020).

As a result of rapidly increasing use during the pandemic, it can cause environmental burdens. The advantages of cloth masks in addition are washable and reusable, namely provide an advantage when it came to reducing waste and pollution. Washing cloth masks are also required decontamination. Most cloth masks are hydrophilic (water immersion). In contrast to highly hydrophobic medical mask materials, home fabrics can permeate and withstand droplets. While the ability to withstand this hydrophilic fabric may have possible benefits in terms of the performance of resisting droplets from homemade masks, it also means that the fabric can withstand viruses that are in wet droplets. Homemade cloth masks should be washed regularly to remove contamination, either using a washing machine in warm temperatures, or hand-washed using household water and disinfectants. Cloth masks should also be worn no later than 4 hours a day (Aydin et al. 2020). But used cloth mask need to give more attention such as the physical properties of a cloth mask, reuse, the frequency and effectiveness of cleaning, and increased moisture retention, may potentially increase the infection risk (., ., and Hidayah 2010).

Table 1.2

Where to Buy Masks during the COVID-19 Pandemic

\begin{tabular}{lll}
\hline Place to Buy & Number of Respondents & Percentage \\
\hline Offline Store & 7 & $14 \%$ \\
Online Store & 43 & $86 \%$ \\
\hline Total & $\mathbf{5 0}$ & $\mathbf{1 0 0 \%}$
\end{tabular}


Third, the place where to buy masks is finding as can be seen in Table 1.2, almost all respondents from this study, namely as many as 86 percent of respondents bought masks through online stores. In addition, 14 percent of respondents bought masks in offline stores. Online stores are a widely chosen choice due to the implementation of PSBB in Surabaya for several months, which causes people to be encouraged to always be at home while fulfilling the household needs so that the various services offered online to become a bestselling option in Surabaya. During PSBB, the informants meet various daily needs through online stores, including masks. They said buying through online stores is safer and more hygienic than buying through the offline store during the pandemic. Meanwhile, the informants who buy masks through offline stores say that they bought masks in offline stores unplanned in advance, for example when they were forced to go outside because of an urgent matter and they saw a merchant or store selling masks.

Nowadays, shopping has evolved as a reflection of lifestyle and recreation in certain economy class communities, especially for upper-middle-class people. Shopping needs at this time are increasing sharply, especially for people living in big cities such as Surabaya. Indonesian consumers have a high heterogeneity due to differences in ethnicity, regionalism, and economic level. This difference concerns habits and lifestyles, especially eating habits, consuming styles, even consumer behavior. Based on the COVID-19 Impact Demographics Social Survey conducted by the Central Statistics Agency (BPS), 54 out of 100 millennial respondents who shopped online during COVID-19 are women. A survey conducted by the Central Statistics Agency (BPS) showed that respondents admitted to shopping online due to the people restrain from physical activities in this coronavirus pandemic. According to a survey from BPS, 31 percent of respondents admitted to experiencing an increase in online shopping activities and 28 percent decreased. As for those who experienced an increase, there was a 42 percent increase in their activities shopping online (BPS 2019). Shopping is one of the interesting activities carried out for women. Although not all women love shopping, it must be recognized that most women love these activities. 
The implementation of Large-Scale Social Restrictions (PSBB) causes people to limit activities outside the home as a result online shopping grew rapidly. Many factors influence individuals to choose online shopping. They are as follows, consumers can buy goods at any time without going to the store, consumers can get products at lower prices by comparing various shopping platforms, consumers sometimes want to avoid pressure when interacting face-toface with sellers, consumers can avoid traffic jams on the way to the store, to avoid the spread of the virus through cash payment transactions so that online purchases become a more appropriate choice. These factors can be summarized into four categories, namely convenience, information, products, and services available, and cost and time efficiency (Katawetawaraks and Wu Lang 2011). This is what affects people's spending patterns that are shifting from offline shopping to online. Based on Analytic Data Advertising (ADA) data, there was a drastic increase in online shopping activities in March 2020. The use of online shopping apps for buying and selling daily necessities, increased by up to 300 percent. The increase comes after the government announced the implementation of social distancing policies. The peak occurred on March 21-22, 2020 where online transaction activity on the app jumped by more than 400 percent. Similar data was also shown by the results of a survey from YouGov in 'COVID-19 Impact on Indonesian Consumer Behavior' which mentioned a 20 percent increase in online shopping (Tempo 2020).

Lifestyle changes from offline to online during the pandemic, especially in economic activities such as shopping, can be proven by internal data from one of the popular shopping platforms in Indonesia, PT Tokopedia. The data shows an upward trend in transactions, especially for health products and other necessities since the COVID-19 pandemic took place in Indonesia. The most sought-after products by consumers are mouth masks, antiseptic liquids or hand sanitizers, and various healthy snacks (Tokopedia 2020). The COVID-19 pandemic that is still spreading in Indonesia has caused online transactions to surge. The reason is that the government's call to do all activities from home can help reduce the spread of COVID-19. The COVID-19 pandemic emergency also brings changes in people's behavior toward shopping. Shopping changes that originally consisted of offline and online shopping, at the time of this pandemic have turned to online only. This is the impact of social restrictions or Physical Distancing that must be lived by the 
Tedjomurti: Behavior Trend Of Buying

Mask As A New Lifestyle For Women In

The City Of Surabaya During Pandemic

community to avoid the spread of COVID-19. Moreover, in some areas and shopping centers began to be closed to the public. The closure was carried out due to the large-scale Social Restriction (PSBB) policy set in some areas. In addition, in spending goods, there is also a slight change. A study was conducted by tracking Indonesian people's online shopping interest in several products during the COVID-19 pandemic. The instruments used to determine consumer interest are impression data in Google Analytics, and the data is taken by comparing the periods 1-29 February and 1-29 March 2020. The results of the research are known that the products that experienced a surge in interest are health products, food, beverages, tools to support hobbies, as well as work from home (IPrice 2020). This study also found that informants enjoy spending their time online shopping for various purposes, they said that browsing various masks on online shopping gives joy during the pandemic.

Table 1.3

Criteria that Consumers Pay Attention to Before Buying a Mask

\begin{tabular}{lllllll}
\hline Consideration & of & Yes & \multicolumn{3}{l}{ No } & \multicolumn{3}{c}{ Total } \\
\cline { 2 - 7 } Criteria & Total & $\mathbf{( \% )}$ & Total & $\mathbf{( \% )}$ & Total & $\mathbf{( \% )}$ \\
\hline Design & 30 & 60 & 12 & 24 & $\mathbf{4 2}$ & $\mathbf{8 4}$ \\
Theme & 38 & 76 & 4 & 8 & $\mathbf{4 2}$ & $\mathbf{8 4}$ \\
Price & 23 & 46 & 19 & 38 & $\mathbf{4 2}$ & $\mathbf{8 4}$ \\
Color & 39 & 78 & 3 & 6 & $\mathbf{4 2}$ & $\mathbf{8 4}$ \\
Brand & 1 & 2 & 41 & 82 & $\mathbf{4 2}$ & $\mathbf{8 4}$ \\
\hline
\end{tabular}

Source: private data

Fourth is about what criteria consumers consider before buying a mask. A total of 84 percent of respondents chose to buy a mask by always considering some of the criteria on the mask. Furthermore, as many as 16 percent of respondents said that the criteria on the mask are not very important. Some of the criteria considered by women in Surabaya before purchasing masks dealt with the brand of masks, the color of masks, motifs or models of masks, as well as the price of the masks. An informant stated that the color factor and the motif become a consideration for them to buy cloth masks because they like to mix match 
between the clothes worn with the mask to be used, so some informants say that they collected masks to facilitate the process of mixing fashion. Especially for those who have a difficult job they often meet people. The informant considers that if the clothes and masks worn look harmonious can charm their appearance.

Related to these findings, masks with colors, models or motifs, and attractive prices and according to taste became the considerations by women in Surabaya before buying masks. The purchase of masks in Surabaya, especially by women, has shifted in terms of health into a trend that makes masks part of fashion. This is also the case in the United States, where a headline in a New York Times article in March 2020 said about the role of masks during the COVID-19 pandemic. Masks have become a decoration (complement) of clothing worn anywhere and anytime. In 2020 the production and sale of masks began to take shape. There are various forms, models, and materials used and advertised (Matuschek et al. 2020). Their actions can be called consumerism because they buy no longer because of a need, the function of masks has increased not only about health but also about fashion. Consumptive behavior should be avoided so as not to take root in a person and become a lifestyle so that they can consider the needs and desires (Suparti 2016). To align with the outfit to be used, the informants are willing to look for masks that match the clothes they will wear. One of the studies found's said that lifestyle can influence a person's behavior and can also determine one's consumption choices (Pratiwi 2015).

Human life is the process of consumption, in other words, it is a consumer society which means that everything is sold, to exchange for just fulfilling the desire to own an item, including objects, services, body, sex, culture, science, and so on (Baudrillard 2013). According to Baudrillard, the emergence of consumer society is an effort to organize the needs of the community and to integrate it into a system designed and to replace all open interactions between the forces of nature, needs, and technology. Technology according to Baudrillard plays an important role, especially human beings as agents that spread the images to a wide audience. During the COVID-19 pandemic, at home, technology is important because various activities are carried out during PSBB, such as for work, school, and do not miss meeting daily needs such as eating and others. Everyone's decision to buy or not is entirely influenced by the power of the image. The soaring number 
of online shopping activities due to minimizing outdoor activities at first is just a fulfillment of basic needs such as food, beverages, and other household needs, but over time the goods purchased increase into secondary items. According to the study in Vietnam show that there is a significant change in the perception of the benefits of online shopping for consumers during the Covid-19 epidemic (Pham, Do Thi, and Ha Le 2020). This item has no significant useful value in everyday life, it is more to the fulfillment of entertainment needs alone, such as taking up new hobbies, or just doing certain things. This attitude is just fulfilling the desire to have an item, not because of a need. Masks are simple, cheap, and potentially effective. Worn both in the home (particularly by the person showing symptoms) and also outside the home in situations where meeting others is likely, it could have a substantial impact on transmission with a relatively small impact on social and economic life (Greenhalgh et al. 2020). But most important is about how the user is educated on the different types of masks available, how and when to wear them, and, above all, how to handle them correctly, similar to the safety instructions given before taking of in an aircraft (Matuschek et al. 2020).

Figure 2.

The Behavior of Women in Buying Masks during Pandemic in Surabaya

Women
buying
mask to
support
health, there
is useful
value on
mask.

\begin{tabular}{|} 
Technology \\
has \\
important \\
role to \\
affect \\
woman.
\end{tabular}

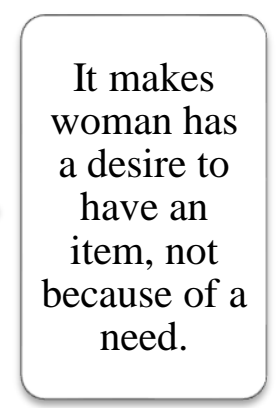

Woman buying mask for the design, color etc. There is no useful value anymore.

\section{CONCLUSION}

The COVID-19 pandemic that began to be detected in Indonesia in early March 2020 has affected various areas of people's lives. Several efforts continue to be taken by the government to precaution the spread of the COVID-19 virus, one of which is by requiring the wearing of masks when doing activities outside the home or in public spaces. Masks have different types that can be used by the 
community and certainly have different functions according to their respective types. The trend of masks that emerged in the community during the COVID-19 pandemic, gave rise to a new phenomenon, where there is a shift in the function of masks, especially in women in Surabaya. This is demonstrated by the findings of this study, the first of which is that more than half of respondents from this study purchased 10 to 20 masks during this pandemic. Secondly, most women in Surabaya chose to buy a type of cloth mask for several reasons, namely the scarcity of medical masks and the soaring price, the fabric masks have a variety of motifs and colors that look more attractive to use, and cloth masks can be used again after washing properly. The third is also known that most respondents from this study bought masks through online shopping platforms due to the ease and practicality factor during the PSBB (lockdown) period in Surabaya. Furthermore, the buyers of cloth masks in this study were women in Surabaya, who attached importance to the color factor, model, motif, price, and brand of the mask to be purchased. So, in urban communities, masks have become a trend that is part of the new lifestyle of Surabaya's women. In addition, masks also have the value of signs or symbols as a tool to beautify themselves, especially for women. Furthermore, they have useful value in terms of health, namely as an inhibitor of the spread of the virus, The value of masks for women in Surabaya has shifted, not only as a tool to support health while in a public place but in addition masks have become part of fashion, especially the type of cloth masks. So that the colors, materials, motifs, and decorations on the mask become an important criterion factor in consideration of the purchase of masks. Jean Baudrillard states that consumerism in modern society has put aside the value to accentuate the value of signs or symbols attached to an item, the theory is in line with the phenomenon found where during the COVID-19 pandemic, the background of the purchase of masks by women in Surabaya is more concerned with the value of signs or symbols attached to the goods, namely to match clothes with masks to look more aligned and attractive to look at, compared to its use value in terms of health. According to Baudrillard, consumerism in modern society is more concerned with the value of symbols and overriding the useful value of the goods. The purchase of masks, especially for women in Surabaya, is no longer only seen in terms of use-value as an impediment to the process of spreading the virus, but as the value of symbols in it, namely, as an item used to beautify themselves. Women in 
Tedjomurti: Behavior Trend Of Buying

Mask As A New Lifestyle For Women In

The City Of Surabaya During Pandemic

Surabaya have considered masks as part of fashion, so it is considered as a symbol embedded in the item.

The advice for further research is to add male respondents as another variation. Furthermore, by increasing the number of respondents as well as more digging information from these respondents, so that the information obtained is more indepth and detailed. Further research can also be done again to update the findings of the data, where conditions in the field may have already undergone some changes. The use of masks should also pay attention to the benefits, the use of cloth masks in addition to the recommendations given by the Government, cloth masks are preferred by the general public to get maximum protection during the pandemic, but in addition, the use of masks must be followed by other health protocols such as keeping a distance and frequently washing hands in the right way, wash your mask with tap water and laundry detergent or soap, rinse thoroughly with clean water to remove detergent or soap, then dry your mask completely in a warm or hot dryer (Cdc 2020). Awareness of yourself and the role of the government to always remind the public to always comply with health protocols that have been made are important to create a healthy environment.

\section{REFERENCES}

Marsaid, . Hurun Ain, and Nurul Hidayah. 2010. "Hubungan Antara Kebiasaan Menggunakan Masker Dengan Terjadinya Batuk Pada Pekerja Industri Mebel Di Desa Karangsono Kecamatan Sukorejo Kabupaten Pasuruan.” Jurnal Keperawatan 1(2):118-25. doi: 10.22219/jk.v1i2.405.

Atmojo, Joko Tri, et al. 2020. "Penggunaan Masker Dalam Pencegahan Dan Penanganan Covid-19: Rasionalitas, Efektivitas, Dan Isu Terkini." Avicenna: Journal of Health Research 3(2):84-95. doi: 10.36419/avicenna.v3i2.420.

Aydin, Onur, Bashar Emon, Shyuan Cheng, Liu Hong, Leonardo P. Chamorro, and M. Taher A. Saif. 2020. "Performance of Fabrics for Home-Made Masks against the Spread of COVID-19 through Droplets: A Quantitative Mechanistic Study." Extreme Mechanics Letters 40:100924. doi: 10.1016/j.eml.2020.100924.

Baudrillard, Jean. 2013. Masyarakat Konsumsi. Yogyakarta: Penerbit Kreasi Wacana. 
BPS, Surabaya. 2019. "Data Jumlah Penduduk Perempuan per Kecamatan Di Kota Surabaya Pada Tahun 2019.” Retrieved (bps.go.id).

Cdc, Gov. 2020. "Use Masks to Slow the Spread of COVID-19." Retrieved June 15, 2020 (https://www.cdc.gov/coronavirus/2019-ncov/prevent-gettingsick/diy-cloth-face-coverings.html ).

Chua, Ming Hui, et al. 2020. "Face Masks in the New COVID-19 Normal: Materials, Testing, and Perspectives." Research 2020:1-40. doi: $10.34133 / 2020 / 7286735$.

Chughtai, Abrar A., Seale, Holly, Macintyre, C. Raina. 2020. "Effectiveness of Cloth Masks for Protection Against Severe Acute Respiratory Syndrome Coronavirus 2."

Cumbo, Enzo, and Giuseppe Alessandro Scardina. 2021. "Management and Use of Filter Masks in the 'None-Medical' Population during the Covid-19 Period.” Safety Science 133:104997. doi: 10.1016/j.ssci.2020.104997.

Gandhi, Monica, Chris Beyrer, and Eric Goosby. 2020. "Masks Do More Than Protect Others During COVID-19: Reducing the Inoculum of SARS-CoV2 to Protect the Wearer." Journal of General Internal Medicine 35(10):3063-66. doi: 10.1007/s11606-020-06067-8.

Greenhalgh, Trisha, Manuel B. Schmid, Thomas Czypionka, Dirk Bassler, and Laurence Gruer. 2020. "Face Masks for the Public during the Covid-19 Crisis.” The BMJ 369(April):1-4. doi: 10.1136/bmj.m1435.

IPrice, Id. 2020. "Tren Belanja Online Selama Pandemi COVID-19 Di Indonesia." Retrieved June 15, 2020 (https://inet.detik.com/cyberlife/d4971620/tren-belanja-online-selama-pandemi-covid-19-di-indonesia).

Katawetawaraks, Hayapa, and Cheng Wu Lang. 2011. "Online Shopper Behavior: Influences of Online Shopping Decision.” doi: 10.14707/ajbr.110012.

Li, Y., T. Wong, J. Chung, Y. P. Guo, J. Y. Hy, Y. T. Guan, L. Yao, Q. W. Song, and E. Newton. 2006. "In Vivo Protective Performance of N95 Respirator and Surgical Facemask." American Journal of Industrial Medicine 49(12):1056-65. doi: 10.1002/ajim.20395.

Matuschek, Christiane, et al. 2020. "Face Masks: Benefits and Risks during the COVID-19 Crisis." European Journal of Medical Research 25(1):1-8. doi: 10.1186/s40001-020-00430-5.

Matusiak, Łukasz, Marta Szepietowska, Piotr K. Krajewski, Rafał BiałynickiBirula, and Jacek C. Szepietowski. 2020. "The Use of Face Masks during the COVID-19 Pandemic in Poland: A Survey Study of 2315 Young Adults." Dermatologic Therapy 33(6):3-5. doi: 10.1111/dth.13909. 
Paret, Michal, Jennifer Lighter, Rebecca Pellett Madan, Vanessa N. Raabe, Gail F. Shust, and Adam J. Ratner. 2020. "Ac c Ep Te d Us Cr Ip t Ac c Ep Te d Us Cr T." (646):1-8.

Pham, Van Kien, Thu Ha Do Thi, and Thu Hoai Ha Le. 2020. "A Study on the COVID-19 Awareness Affecting the Consumer Perceived Benefits of Online Shopping in Vietnam." Cogent Business and Management 7(1). doi: 10.1080/23311975.2020.1846882.

Pratiwi, Galih Ika. 2015. "Perilaku Konsumtif Dan Bentuk Gaya Hidup.” Jurnal Mahasiswa Sosiologi 1-21.

Putri, Santy Irene. 2020. "Studi Literatur: Efektivitas Penggunaan Masker Kain Dalam Pencegahan Transmisi Covid-19.” Jurnal Kesehatan Manarang 6(khusus): 10 .

Sumartono. 2002. "Terperangkap Dalam Ikla Meneropong Imbas Pesa Iklan Televisi."

Suparti. 2016. "Mitigating Consumptive Behavior: The Analysis of Learning Experiences of Housewives." doi: 10.5539/ies.v9n3p114.

Tempo, co. 2020. "Riset: Belanja Online Meningkat Pesat Di Tengah Pandemi Covid-19." Retrieved June 15, 2020 (https://bisnis.tempo.co/read/1331198/riset-belanja-online-meningkatpesat-di-tengah-pandemi-covid-19/full\&view=ok).

Tokopedia. 2020. "Jual Beli Online Pendongkrak Ekonomi Di Masa Pandemi Covid-19." $\quad$ Retrieved June 15, 2020 (https://yoursay.suara.com/news/2020/06/26/130654/jual-beli-onlinependongkrak-ekonomi-di-masa-pandemi-covid-19?page=all).

WHO. 2020. "Advice on the Use of Masks in the Context of COVID-19." Who (April):1-5. 